\title{
The Effect of Trade Liberalization on Chinese Rural Poverty
}

\author{
Shixin Li \\ Management College, Hunan University of Science and Technology \\ Xiangtan 411201, Hunan, China \\ E-mail: stonelsx@126.com
}

\begin{abstract}
There has been much controversy over the impacts of trade liberalization on poverty. Some have argued that trade liberalizations are beneficial to the poor in developing countries, while others have argued that the gains will be captured more by the non-poor. The policies of trade liberalization in China have reduced the NPRs of some agricultural products, which cut down the welfare of its producers, but the expansion in foreign trade of agricultural products rapidly reduces rural poverty. The change in foreign-trade construction of agricultural products not only impacts the welfare level of different kinds of agricultural producers, but also makes the farmers in coastal areas be the greatest gainers. This paper applies SURE with simultaneous-equations to assess the link of trade-poverty in China, and its result shows that the link of trade-poverty in China is characterized by inverted U-shape. That is, before the mid 1990s, trade liberalization in China worsens the rural poverty; and after then it is beneficial to rural poverty reduction.
\end{abstract}

Keywords: Rural poverty, Trade liberalization, Trade of agricultural products, SURE

\section{Introduction}

China has made remarkable progress in poverty reduction since the launching of economic reform in the late 1970s. According to the official poverty line, the rural poor population in China has declined dramatically in the past 30 years, from 260 millions in 1978 to 14.79 millions in 2007. Namely, one of significant success of China is having removed more than 245 million rural residents out of poverty. At the same time, the incidence of rural poverty has also decreased sharply during the transition period, falling from $32.9 \%$ in 1978 to $2.1 \%$ in 2007 . Even according to the international poverty line (one dollar for each person every day in term of the Purchasing Power Parity), the same conclusion can be drawn that both the absolute poverty and incidence of poverty have dropped notably (See table 1). Comparing with other developing countries, the success in Chinese rural poverty reduction is more significant. If China is not included, the absolute number of the population below the poverty line in developing countries has actually increased by 100 million in the 1990s (ESCAP, 2003), and the incidence of poverty in developing and transiting countries has also declined only from $28 \%$ to $24 \%$ within 1978-1998(World Bank, 2001).

\section{INSERT TABLE 1 HERE}

Another remarkable success of China is the expansion of external trade due to the policy of opening-up. The growth rate of foreign trade exceeded the growth rate of GDP during the reform era. The average annual growth rate of foreign trade was close to $15 \%$ in the 1980 s and the early 1990s. Though Asian financial crisis exerted some negative effects on the foreign trade (its annual growth rate is only about 10\% during 1996-2000), the foreign trade of China has been expanded rapidly at the six years following China's accession to WTO in 2001. At the same time, with rapid growth in the volume of foreign trade, foreign trade has played more and more role in national economy. The proportion of total import and export value to GDP has increased from $9.8 \%$ in 1978 to $77.3 \%$ in 2007 . The total volume of trade for the Chinese primary products (mainly agricultural products) has risen from 16,100 million. U.S. dollars to 72,100 million dollars during 1980-2001, increasing by $7.4 \%$ every year (NSBC, 2002).

Though China has made great achievements both in the poverty reduction and in foreign trade since reform and opening-up, existing studies still seldom connect these two respects. Current studies on poverty reduction in China mainly focus on analyzing the impact of the economic growth on poverty (Wei Zhong, Gustafson, 1998; Lin BoQiang, 2003) and investigating the efficiency of the national anti-poverty program and anti-poverty investment policy (World Bank, 1992; Fan, etc., 2002; Park, etc., 1998). Analyzing about the effects of foreign-trade growth on the Chinese rural 
poverty has been neglected in researches. Therefore the main purpose of this paper is to assess, using both descriptive analysis and empirical test, the extent to which the growth of external trade may affect poverty in rural China. The empirical research draws an important result that the effect of trade liberalization on poverty in rural China is characterized by an inverted $U$ shape.

Remaining parts of this paper is organized as follows. Section II presents opposite views about the effect of trade liberalization on poverty. Some argue that external trade liberalizations are beneficial to the poor in developing countries, while others have argued that the benefits are captured more by the non-poor. A describing analysis about the effect of trade liberalization on the rural poverty reduction in China is presented in Section III. In the IV section, the paper tests wholly the evidence about the impact of trade liberalization on the Chinese rural poverty. The last section gives a short policy application to the result of this paper.

\section{Debates about the issue}

In present studies, there has been much controversy over the link of trade-poverty. Some scholars focused on the positive static and dynamic effect of trade liberalization on economic growth, and argued that external trade liberalizations are beneficial to the poor in developing countries. On one hand, as emphasized by conventional trade theory, static economic gains refer to the role of reallocating resources that trade liberalization play in the process of economic growth. That is, under greater trade liberalization, productive resources tend to be reallocated toward activities where they are used with comparatively greater efficiency and away from less efficient activities (such as import-substitution industries or rent-seeking activities).

On the other hand, the literature on endogenous growth has emphasized the existence of dynamic gains in external trade, which are generated through various economic mechanisms and thereby affect the rate of economic growth in the long run. Particularly, it has been suggested that trade liberalization may facilitate the acquisition of various new inputs, expensive and higher-quality intermediate goods and improved technologies, which enhance the overall productivity of the economy. In the model of Romer (1994), a greater variety of inputs do more for production than a greater quantity of a narrow range of inputs. Because only a narrow range of specialized intermediate goods can be profitably produced in an economy where external trade is restricted, access to a variety of foreign inputs at a lower cost may shift the production possibility frontier outward, and thereby may raise the economy-wide productivity. Moreover, the mechanism through which increased productivity and growth rates occur as an economy liberalize its foreign trade is not limited to the acquisition of more specialized intermediate inputs and advanced machinery from trading partners; there are still many types of useful knowledge that are not embodied in material inputs (such as production engineering and information about changing product patterns), but can also be transferred as a result of trade with more advanced countries. As argued by Romer (1992), in practice, the transmission of ideas may be important as, if not more important than, the transmission of new inputs.

Besides theoretical analyses, there is some empirical evidence arguing that trade liberalization has positive impacts on economic growth. Studies by Irwin and Tervio (2002) suggested that households have higher incomes in countries where foreign trade is liberalized. Using a computable general equilibrium framework, which is more recent theories of trade and growth, Klenow and Rodriguez-clare (1997) accounted for product variety effects through a production function in which fewer intermediate input varieties lead to productivity losses and lower output, despite the same capital and labor inputs. They found that accounting for such effects can quadruple the static gains from unilateral trade liberalization. The empirical studies by Wacziarg (1998) found that external trade is the most important channel through which the learning-by-doing and growth effects of these spillovers occur. They found that these effects are largest in countries with higher levels of education. Finally, a recent study by the World Bank (2002) suggests that the developing countries where the levels of trade liberalization are highest in the last two decades have averagely grown the fastest. These countries managed to reduce import tariffs, on average, by 34 percentage points since 1980. Comparatively, there was no growth in per capita incomes over the period in those developing countries whose average import tariffs only dropped 11 percentage points.

Views mentioned above prove that foreign trade is good for growth. And growth is allegedly good for the poor (For example, Dollar and Kraay (2001) claimed that increased growth raises averagely the incomes of the poor in proportion to those of the population). Therefore, these scholars conclude that trade liberalization is good for the poor.

However, some other scholars have argued that the benefits will be captured more by the non-poor and the effect of trade liberalization on poverty reduction is negative at some time. Wholly, causes they provided for this can be summarized into four points as following.

First, the static effect of trade liberalization is not confirmed in a short run. As mentioned above, under trade liberalization, productive resources in an economy can be used more efficiently in the long run, and thereby higher growth rates and lower poverty can be enjoyed. But in the short term, opening a country's markets to foreign firms tends to reduce the market power of domestic firms and exert greater competitive pressures on them, even forcing some 
of them out of business. The inability to compete, as well as the presence of labor market rigidities (segmentation due to minimum wage legislation, wage-setting behavior by firms or trade unions, or register system, as well as imperfect mobility across sectors), may hamper the reallocation of labor among sectors, especially between nontradables and tradables that usually enjoy a reduction in tariffs (Agénor and Aizenman, 1996). As a result, both unemployment and poverty may increase and persist over time.

Second, it is difficult, in short run, to play role for the effects of scale economies and learning-by-doing, which are emphasized in the new theories of trade and growth. These effects usually take place in an economy producing advanced manufactured products, such as high-technology goods. However, if a country is lagging behind technologically and has an initial comparative advantage in lower-technology sectors, trade liberalization may reduce the growth rate (Matsuyama, 1992). Indeed, exports of most developing countries mainly consist of raw materials (including energy and agricultural products) and relatively low-technology manufactured goods (such as textiles). Even though trade liberalization may be beneficial for these developing countries to assimilate advanced production techniques and technologies and thereby enable them to shift toward the production of goods and services through which the dynamic effects of trade liberalization can be gained, there may still be a transition period during which these effects may be limited. It has also been argued that the expansion of foreign trade may discourage activities of domestic research and development, for instance by inducing these developing countries to allocate too much of their limited skilled labor to the activities of producing manufactured goods. In such conditions, paradoxically, restrictions on trade may accelerate growth.

Third, trade liberalization may also negatively affect poverty reduction by decreasing the demand for unskilled labor and widening income gap. For instance, in some countries of Latin America, the policies of trade liberalization during the 1980s and 1990s has led to an decline in the demand for unskilled labor and worsening income distribution. A studies by Beyer, Rojas, and Vergara (1999) found that trade liberalization, as measured by the volume of trade over GDP, widened the wage gap between skilled and unskilled labor during this period in Chile. A possible explanation for this phenomenon is that trade liberalization and greater openness has introduced advanced and higher-level technology, the use of which requires skilled labor. The reason is that the cost of imported capital goods depends largely on tariffs that are incurred in purchasing a unit of capital goods abroad. Therefore, trade liberalization may lead to lower import tariffs, which may translates into a fall in the cost of capital goods, further leading to an increase in the use of capital. Because there is a high degree of complementarity between skilled labor and capital, and a high degree of substitutability between unskilled labor and capital, more capital used in economy would require more skilled labor and less unskilled labor. Thereby, if the supply in both categories of labor is constant, the demand for skilled labor would increases and the demand for unskilled labor would decreases, which would widen the wage gap between skilled and unskilled labor. All of these may translate into higher unemployment for unskilled labor and worsened income distribution, and eventually worsening poverty.

Finally, trade liberalization in developing country is unfavorable to the accumulation of human capital, which is an important indicator of broadly-defined poverty. Some theoretical models suggest that, in countries where skills are initially scarce, trade liberalization may lead to a decrease in the accumulation of human capital, which limits the ability of the poor to increase income and to break away from the poverty. For instance, Findlay and Kierzkowski (1983) used a model of perfect capital markets to analyze the accumulation of human capital and the supply of skilled labor in countries that are initially skills-scarce. They found that trade liberalization makes cheaper skills-intensive import goods available and decrease in demand for skilled labor, which may reduce the rewards to education and lower the accumulation of human capita. His analysis is based on the assumption of credit constraints, which limit the ability of unskilled workers to finance the education needed to become skilled.

The debate is still continuing. There are two main reasons for the difference in views. The first is that different observers analyzed the issue with different assumptions and thereby drew different conclusion. The second is that the link of trade-poverty changes notably in various countries and thus studies with different cases of various countries usually lead to opposite views. In whole, the comparatively accurate conclusion may come from the analysis of special country case. Thus, this paper only analyzes the case of the post-reform China in the following sectors.

\section{A descriptive analysis}

Since the end of 1978, besides implementing a series of economic reform measures, China has also pursued progressively the policies of trade liberalization, mainly including reducing import tariff, cutting down or canceling import quota, removing government's control on external trade, free convertibility of RMB (currency in China) under current account. These policies of trade liberalization have not only promoted the rapid growth of national economy, but also have exerted great influences on the expansion in the foreign trade of Chinese agricultural products and the change in China rural poverty.

First, the trade liberalization has reduced the nominal protection rates of relevant agricultural products and affected largely the change of rural poverty. Since reform and openness-up, through progressively reducing the tariff rates and 
removing most of import quota, China has decreased the average tariff rate from $52.3 \%$ in initial stage of reform to $11 \%$ in 2003 and largely adjusted the protective measures of external trade. The downward modulation of the tariff has made the nominal protection rates (NPRs) drop (see table 2). A Study by Huang, Rozelle and Chang (2004) indicated that the nominal protection rates of agricultural products in China dropped sharply during 1980-2001. With China's accession to WTO in 2001, the nominal protection rates have further dropped and will continuously drop in the future five years. The decline of the nominal protection rates has made the price of domestic market draw progressively close to the international price, to some extent that have removed the twist of domestic price. Removing the price twist has optimized resource distribution, promoted the economic growth, and thus helped to reduce the rural poverty. At the same time, however, it has also reduced the protection for some domestic agricultural products, and exerted competitive pressure on the producers of these goods. Especially, weakening the protection for agricultural products such as the wheat, maize, cotton, corn and soybean, etc., has reduced its export, thus affected negatively the welfare of those peasants who product these goods.

\section{INSERT TABLE 2 HERE}

Second, the trade liberalization has promoted the growth of agricultural product trade, thus improved the welfare of farm households. During the reform period, thought the proportion of the volume for agricultural product trade to the volume for total trade decreased constantly, the total external trade volume of agricultural products increased progressively and kept in favorable balance state at all times. The import of the food and fodder has increased from 2916 million U.S. dollars in 1980 to 10,475 million dollars in 2003, while the export of the same products has increased from 2,972 billion U.S. dollars to 17,255 billion dollars during the same period (see table 3 ). The expansion in the foreign trade of agricultural products increased largely the income levels of farm households, and thus was beneficial to reducing the rural poverty in China.

\section{INSERT TABLE 3 HERE}

Finally, the trade liberalization has promoted the change in the foreign trade structure of agricultural products and impacted largely the welfare levels of farm households. Just as what the traditional trade theory shows, the change in the external trade structure of China's agricultural products since reform and openness has reflected the comparative advantage characteristic of China's agricultural trade. The net export of the land-intensive products (such as the cereal, rape seed and sugar crops) declined and the net export of labor-intensive products (such as horticulture products and livestock products) that have high added value increased (table 3 ). This structure change has exerted two effects on the welfare levels of farm households. First, it has changed the welfare levels of different farm households who produced different agricultural products. On one hand, the expansion in the net export of labor-intensive agricultural products has increased the income of farm households who produced these goods, has raised the education levels of their children, and thus has improved the conditions of this kind of poor rural population. On the other hand, the decline in the net export of land-intensive agricultural products has worsened the income distribution of farm households who produced these goods, has decreased the education levels of their children, and thus has worsened the condition of this kind of poor rural people. Second, it has made farm households in different areas be benefited unequally. Farmers in coastal areas have more and better produced the products that have comparative advantage at present, such as rice, the livestock and horticulture products. The proportion in the total export of these products has risen and thus its net export kept increasing constantly. Oppositely, farmers in inland areas have trended to plant agricultural products that do not have comparative advantage, such as wheat, soybean and cotton. The proportion in the total export of these products kept dropping, and thus its net export kept declining constantly. Therefore, comparing to the farm households in inland areas, the farmer households in coastal areas became the greater gainer in the process of the trade liberalization.

These two effects of the change in foreign trade structure of agricultural products can be proved by the data in table 4 . The first effect can be confirmed by the information in the table as following: Lower is income per capita of farm households, larger is the proportion of their land- intensive agricultural products, which are less competitive in international markets; higher is income per capita of farm households, larger is the proportion of their labor-intensive agricultural products, which are more competitive in world markets. For example, $64 \%$ of the income for farm household group with lowest income in western areas came from agricultural products that are less competitive; $72 \%$ of the income for farm household group with the highest income in east areas came from agricultural products that are more competitive. The second effect can be confirmed by the information in the table that income per capita of farm households who live in inland areas is lower and income per capita of farm households who live in coastal areas is higher. For example, income per capita of the poorest rural household group in the western regions is only 356 Yuan, which is only $60 \%$ of the income of the poorest rural household group in coastal areas (598 Yuan). Income per capita of the richest rural household group in the eastern areas is 8040 Yuan, which is more than twice times of the income per capita of the richest rural household group in the western areas (3961 Yuan).

\section{INSERT TABLE 4 HERE}

Prospecting the future indicates that, after China's accession to the WTO, fulfilling its relevant obligations will deepen 
further the policy of trade liberalization. The tariff rate of most import farm goods will continue dropping and nominal protection rates of most agricultural goods will be reduced; the external trade of farm products will continuously expand; and the structure in the foreign of agricultural products will further be adjusted to suit for the demand in international markets. Meeting the commitments in agriculture will directly affect China's agricultural sector plus its food, feed and fiber processors, as well as consumers of food and beverages. Imports of numerous land-intensive farm products may increase, and most observers presume that will put downward pressure on prices received by China's farmers, and thus will exert negative effects on the welfare of farm households. However, reduced protectionism of foreign against China may boost output and exports of some labor-intensive farm products in which China still has a comparative advantage, and thus may produce the positive welfare effect. In addition, farm households will be affected indirectly by many of the other commitments China has made in its WTO Accession Protocol. Especially important will be the arrangements for phasing out the 'voluntary' export restraints on China's textile and clothing trade, and the reductions in protection of the motor vehicles and parts industry. So too will be the myriad commitments affecting the services sector, including state trading enterprises. Those changes, together with the promised increase in a wide range of agricultural imports, will allow China to exploit more fully its strong comparative advantage in unskilled labor-intensive products - both farm and non-farm (Anderson, 1990). All of these may affect positively employment, income, and poverty of households who live below poverty line.

\section{An empirical analysis}

The impact of foreign trade expansion on poverty in rural China is descriptively analyzed above, but more accurate quantitative relation between trade and poverty must be estimated by econometric models. There are two issues must be solved in the estimation of this paper. One is choosing what indexes to measure trade liberalization, and the other is the possible nonlinearity of the relationship between foreign trade and poverty.

It is an arduous task to measure openness, especially, to find a suitable single index of measuring trade liberalization. Various indexes of measuring trade liberalization have been used in existing studies, including tariffs, nontariff barriers, effective rates of protection, relative prices, import penetration, export intensity, and deviations of actual from predicted trade flows or volumes (Harrison and Hanson 1999). It is discovered that choosing single index to measure trade liberalization might bring about some deviations. For example, using the import tariff is unable to state the situation of the non-tariff trade barriers. Therefore, according to the method of Wacziarg (1998), I amalgamate several single indexes and reconstruct them into a composite index of trade liberalization (TRADE). The key step of reconstructing this composite indicator is to determine the weight of each single indicator. The method adopted here for this aim is to regress the trade volume over GDP with these single indicators and other factors. For simplicity, I only choose three single indicators as following: (a) OPEN, the percentage of import-export volume in GDP, which is used to state the degree of openness; (b) TARIFF, the average tariff rate (that is, total tariff revenue divided by the value of imports), which is correlated with the degree of protection; (c) CTOT, the rate of change in the trade terms, which reflect the improvement degree of the foreign-trade environment.

Discussions on this issue usually have focused on the possibility of linear, negative/positive relationships between trade liberalization and poverty. However there are also possible nonlinearities, which have seldom been acknowledged in the debates on the benefits and costs of trade liberalization. Because these nonlinearities may alter the sign of the relationship between foreign trade and poverty, understanding their causes is important not only for theoretical analyses but also for empirical test. For simplicity, I only consider here two types of effects that bring about these nonlinearities. The first is an output effect, which means that trade liberalization may improve the efficiency in the allocation of domestic productivity resources and thus may exert impact on output. According to Greenaway, Morgan and Wright (2002), this effect has a J-curve shape: at first, output falls due to the drop of output in import-competing industries and then increases gradually as a result of the expansion in exportable sectors. Assuming for simplicity a one-to-one, inverse relationship between income and poverty, this implies that trade liberalization has an inverted J-curve effect on poverty.

The second effect of trade liberalization is a relative wage effect, which reflects the change of the skilled-wage differential led by trade liberalization. According to Harrison and Hanson (1999), this effect has an inverted U shape. The skilled-unskilled wage differential increases initially with trade liberalization, possibly because capital goods can be imported increasingly at lower cost and may substitute away unskilled labor. Employment of that category of labor falls initially and poverty tends to increase. Over time, however, the initial widening in wage differentials may lead to investment in human capital and a gradual increase in the supply of skilled labor, which would tend to narrow the wage differential across skill categories, and higher degrees of liberalization may reduce poverty. This second effect may thus take the form of an inverted U-shape relation.

Statement above shows that, operating either through output or relative wages, the initial and longer-run effects of trade liberalization on poverty differ in sign: although poverty may rise in the short run, as output increases and investment in education rises, poverty begins to fall. Therefore, in order to determine the sign of trade-poverty relation, I assume that the relation is quadratic. Thus while using index TRADE, I also used index TRADE ${ }^{2}$; the latter is the square of the 
former.

The dependent variable used in the regression of this paper is poverty incidence (PI), namely the proportion of the poor population to the total population. Besides the index of trade liberalization (TRADE and TRADE ${ }^{2}$ ), the independent variables also include macroeconomic and structural "controlling" variables as following:

(a) Income per capita (PGDP) and its square $\left(\mathrm{PGDP}^{2}\right.$ ), which is used for investigating the impact of the economic growth on poverty;

(b) The income distribution (INE), which captures the impact of the income distribution on poverty and is here substituted by the income gap between the urban and rural areas (the rationality of this substitution has already been verified by scholars (Tsui, 1993) in theory).

(c) The proportion of agricultural output to GDP (AGR), which reflects the impact of agriculture growth on the rural poverty.

(d) The proportion of township-enterprise output to GDP (TVE), which explains how the foreign-trade expansion of township enterprise affects the rural employment and poverty.

(e) The annual inflation rate in term of CPI (INFLATION), which state the impact of fluctuation from the macroeconomic environment on poverty incidence.

Because foreign trade may exert both direct and indirect influences on poverty, for example, through economic growth and income distribution, a simple OLS analytic method with single equation is unable to capture such complicated quantitative relation. Therefore, I adopt the form of the simultaneous equations to estimate the link of trade-poverty.

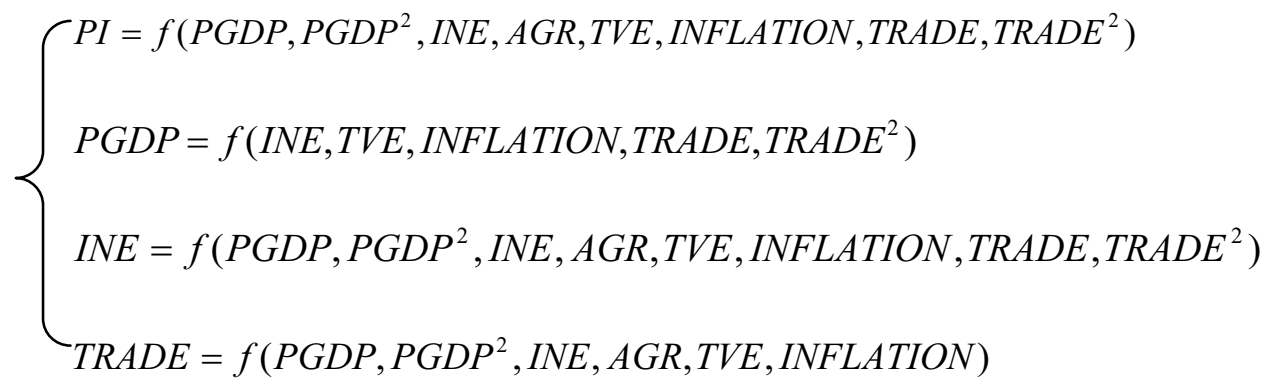

In order to control the dependence of residuals between every equation, I chose Seemingly Unrelated Regression (SURE) as a method for these simultaneous equations to estimate the relation. All data used in the regression are the provincial data for 1985-2003. The result of the SURE with simultaneous equations is provided in table 5.

\section{INSERT TABLE 5 HERE}

The result showed in table 4 suggests that the signs for the estimated coefficients of the variables in the poverty equation are accordant with expectancy. For the "controlling" variables reflecting the changes in macroeconomy, the estimated coefficient of PGDP is significantly negative, which shows that poverty incidence has obviously dropped with the rising of GDP per capita over time. However, the estimated coefficient of PGDP ${ }^{2}$ is positive, which suggests that the declining speed of poverty incidence has been slowed down after GDP per capita rises to certain extent. The estimated coefficient of INE is noticeably positive, indicating that the expansion in income gap between urban and rural areas has heightened the poverty incidence. This result has strong policy application that income distribution inclining towards rural residents may further reduce the poverty incidence under the same conditions.

For the "controlling" variables reflecting the changes in economic structure, the estimated coefficient of AGR is significantly negative, which suggests that the fast growth of agriculture was beneficial to the poverty reduction when economic growth and income distribution are be controlled. The estimated coefficient of TVE is remarkably negative, reflecting the fact that when other factors are controlled, the development of the township enterprise was beneficial to reducing poverty because they have absorbed numerous rural employees. The Estimated coefficient of INFLATION is not statistically significant and its sign is positive, as indicates that the shock of macroeconomic environment in China exert a small positive influence on poverty.

The coefficient of trade-liberalization index is the focal point investigated here. The Estimated coefficient of TRADE is significantly negative and that of TRADE ${ }^{2}$ is positive, which suggests that the link of trade-poverty in China has been characterized by the shape of inverted U. At the initial stage of trade liberalization, poverty in rural China has increased with the constant expansion in foreign trade; and then it has dropped after the trade growth reached some "threshold" value. Note that this estimated result is a net effect of trade liberalization on poverty, without considering the impacts of other factors, especially without considering the effect of economic growth resulted from non-foreign-trade factors. 
This inverted U-shape relation between trade and poverty in rural China can be possibly explained as following. In initial stage for the trade liberalization, the system of household register limited the flow of labor; section segmentation restricted the flow of capital; higher nominal protection rates twisted domestic prices; foreign equipments imported expansively at lower cost took the places of unskilled labor in factories; government's control on foreign trade restrained the behaviors of the maximizing profit. Therefore the gains of the expansion in foreign trade were captured by the non-poor, and thus trade liberalization was unfavorable to the poverty reduction. With the constant promotion of reform and openness, most of the restrictions mentioned above were removed and the efficiency of resource reallocation resulted from the foreign-trade expansion was embodied in economic growth, making it possible that the poor gained more and more from trade liberalization and thus rural poverty in China has declined constantly.

There is a threshold value in the inverted U-shape link between trade and poverty. Shifting from the left of this value to right, its sign changes from positive sign to negative one. If the link of trade- poverty is quadric, we can let $\alpha(\alpha>0)$ be the coefficient of the linear term and $\beta(\beta>0)$ the coefficient of the squared term, and then the threshold value beyond which globalization starts reducing poverty is $-\alpha / 2 \beta$. Therefore, according to the estimated coefficients of TRADE and TRADE ${ }^{2}$ in the poverty equation, it can know that the threshold value in China is 7.61. Using the value of OPEN, TRIFF and CTOT in every period to calculate, conclusion can be draw that this threshold value was reached in the middle of 1990s in China. In other words, the trade liberalization worsened the rural poverty before the middle of 1990s and has been beneficial to reducing poverty after then.

\section{Conclusion and policy application}

There has been much controversy over the impacts of trade liberalization on poverty. Some have argued that external trade liberalizations are beneficial to the poor in developing countries, while others have argued that the gains will be captured more by the non-poor. These debates are due to different assumption and various cases in different countries.

Descriptive analysis on cases in China provided by this paper suggests that the answer of this issue itself is ambiguous. The policy of trade liberalization in China has reduced the nominal protection rates of agricultural products, removed in part the twist of domestic price, optimized resource distribution, promoted economic growth, and thus was beneficial to reducing the rural poverty. In addition, the expansion in foreign trade of the agricultural products has increased the general income of farm households and reduced the rural poverty. However, the decline in the nominal protection rates of some agricultural product has decreased the welfare levels of its producer, and thus was unfavorable to the poverty reduction of farm households who produce this kind of goods. Especially, the change in the foreign trade structure of agricultural products has already impacted the welfare levels of different kinds of agricultural producers, and made farm households in coastal areas become the greatest gainer, which has widened the regional income gap and hindered the steady and continuous reduction of the poverty.

The ambiguous conclusion draw above makes the quantitative analyses on the link of trade- poverty in China necessary. Thus a seemingly unrelated regression with simultaneous equations is adopted in this paper. Conclusion resulted from this regression shows that the effect of trade liberalization in China on poverty is characterized by the shape of inverted U. Namely, the trade liberalization in China worsened the rural poverty before middle period of 1990s, and was beneficial to reducing the rural poverty after then.

The conclusions stated above have important policy applications. The policy makers should at least pay attention to the following several issues.

$>$ The inverted U-shape link of trade-poverty indicates that greater trade liberalization can bring about positive effect on poverty reduction, which requires policy makers further to open their markets to international trade. It is suitable for China to fulfill the legal obligations that China has promised in the WTO Accession Protocol. In addition, various kinds of obstacles restraining resource rational reallocation must be removed progressively as to utilize fully the foreign trade advantage.

$>$ Up till now, the contributions of foreign-trade expansion in China to the rural poverty reduction have come mainly from the export of labor-intensive agricultural products. However, this gain is temporary and difficult to maintain for a long time. Therefore, while fully utilizing the export expansion of labor-intensive products to promote the rural poverty reduction, the technological progress must also be advanced with all strength. For this aim, government must invest more funds to develop education and scientific research, especially to develop education of the poverty-stricken area and agric-scientific research.

$>$ Because the agricultural structural adjustment in coastal areas is suitable to the development of foreign trade, farm households there become the greatest gainer of trade liberalization. Therefore, in order to reduce efficiently poverty, especially the western rural poverty, the agricultural production structure must be adjusted, shifting it from land-intensive production to labor-intensive production.

$>$ Though trade liberalization has brought great gain for the whole country, it also has exerted different welfare impact on different social colonies, which has made the welfare of some households, especially the poor families, 
suffer losses. Thus the compensative domestic policy must be put in place in time in order to adjust and compensate the loser and offer enough security networks for them.

\section{References}

Agénor, Pierre-Richard, and Joshua Aizenman. (1996). Trade Liberalization and Unemployment. Journal of International Trade and Development, 5, September, 265-86.

Anderson, K.. (1992). Changing Comparative Advantages in China: Effects on Food, Feed and Fibre Markets. Beijing: Economic Science Press for the State Planning Commission.

Beyer, Harald, Patricio Rohas, and Rodrigo Vergara. (1999). Trade Liberalization and Wage Inequality. Journal of Development Economics, 59, June, 103-23.

Dollar, David, and Aart Kraay. (2001). Trade, Growth, and Poverty. Policy Research Working Paper No. 2615, the World Bank, September.

ESCAP Economic and Social Commission for Asia and the Pacific of the UNDP. Promoting the Millennium

Fan, Shenggen, Linxiu Zhang, and Xiaobo Zhang. (2002). Growth, Inequality, and Poverty in Rural China: The Role of Public Investments. Research Report 125. Washington, D.C.: International Food Policy Research Institute.

Findlay, Ronald, and Henryk Kierzkowski. (1983). International Trade and Human Capital: A Simple General Equilibrium Model. Journal of Political Economy, 91, December,957-78.

Harrison, Ann E., and Gordon Hanson. (1999). Who Gains from Trade Reform? Some Remaining Puzzles. Journal of Development Economics, 59, June, 125-44.

Huang, J. and S. Rozelle. (2001). The Nature of Distortions to Agricultural Incentives in China and Implications of WTO Accession. Revision (2 April) following its presentation at the second project meeting on WTO Accession and Poverty Reduction in China, World Bank Resident Mission, Beijing, 26-27 October.

Klenow, Peter J. and Andres Rodriguez-Clare. (1997). Quantifying Variety Gains from Trade Liberalization. Unpublished, Graduate School of Business, University of Chicago.

Lin BoQiang. (2003). Economic growth, poverty reduction and policy choice. Journal of Economic research (China), 12, December, 15-25.

Matsuyama, Kiminori. (1992). Agricultural Productivity, Comparative Advantage, and Economic Growth. Journal of Economic Theory, 58, December, 317-34.

NSBC (National Statistical Bureau of China). China rural household survey yearbook, various issues from 1982 to 2002. Beijing: State Statistical Press.

Park, Albert, Sangui Wang, and Guobao Wu. (1998). Regional Poverty Targeting in China. Working Paper, Department of Economics, University of Michigan, Ann Arbor, MI.

Romer, Paul. (1992). Two Strategies for Economic Development: Using Ideas vs. Producing Ideas. The World Bank, World Bank Conference on Development Economics. Washington DC.

Romer, Paul. (1994). New Goods, Old Theory, and the Welfare Costs of Trade Restrictions. Journal of Development Economics, 43, February, 5-38.

Tsui, Kai Yuen. (1993). Decomposition of China's Regional Inequalities. Journal of Comparative Economics, 17, 600-627.

Wacziarg, Romain. (1998). Measuring the Dynamic Gains from Trade. Working Paper No. 2001, the World Bank, November.

Wei Zhong, Gustafson. (1998). Analyzing the change of poverty in China during the transition period. Journal of Economic research (China), 2, February, 64-68

World Bank. (2002). Globalization, Growth, and Poverty. the World Bank, Washington DC.

World Bank. (2001). Attacking Poverty. Oxford: Oxford University Press.

World Bank. (1992). China: Strategy for Reducing Poverty in the 1990s. World Bank, Washington DC. 
Table 1.

Official Government Estimates

International Standards ( $\$ 1 /$ day, PPP)

\begin{tabular}{|c|c|c|c|c|c|}
\hline & $\begin{array}{l}\text { Poverty line } \\
\text { (Current } \\
\text { Yuan) }\end{array}$ & $\begin{array}{l}\text { Poor population } \\
\text { in rural areas } \\
\quad(\text { million })\end{array}$ & $\begin{array}{c}\text { Share of rural } \\
\text { poor population } \\
(\%)\end{array}$ & $\begin{array}{l}\text { Poor population in } \\
\text { rural areas } \\
\text { (million) }\end{array}$ & $\begin{array}{c}\text { Share of rural poor } \\
\text { population }(\%)\end{array}$ \\
\hline 1978 & & 260 & 32.9 & & \\
\hline 1979 & & 239 & 30.2 & & \\
\hline 1984 & 200 & 89 & 11.0 & & \\
\hline 1988 & 236 & 86 & 10.4 & & \\
\hline 1989 & 259 & 102 & 11.6 & & \\
\hline 1990 & 300 & 85 & 9.4 & 280 & 31.3 \\
\hline 1991 & 304 & 94 & 11.0 & 287 & 31.7 \\
\hline 1992 & 317 & 80 & 8.8 & 274 & 30.1 \\
\hline 1993 & 350 & 75 & 8.3 & 266 & 29.1 \\
\hline 1994 & 440 & 70 & 7.7 & 237 & 25.9 \\
\hline 1995 & 530 & 65 & 7.1 & 200 & 21.8 \\
\hline 1996 & 580 & 58 & 6.3 & 138 & 15.0 \\
\hline 1997 & 640 & 50 & 5.4 & 124 & 13.5 \\
\hline 1998 & 635 & 42 & 4.6 & 106 & 11.5 \\
\hline 1999 & 625 & 34 & 3.9 & & \\
\hline 2000 & 625 & 32.09 & 3.4 & & \\
\hline 2001 & 630 & 29.27 & 3.2 & & \\
\hline 2002 & 627 & 28.2 & 3.0 & & \\
\hline 2003 & 637 & 29 & 3.1 & & \\
\hline 2004 & 668 & 26.10 & 2.8 & & \\
\hline 2005 & 683 & 23.65 & 2.6 & & \\
\hline 2006 & 693 & 21.48 & 2.4 & & \\
\hline 2007 & 785 & 14.79 & 2.1 & & \\
\hline
\end{tabular}

Table 2. Nominal Protection Rates of China's main agricultural product (\%) (Tariff or tariff equivalence)

\begin{tabular}{lllll}
\hline Goods & 1995 & 1997 & 2001 & 2010 \\
\hline Rice & -5 & -5 & -3 & 0 \\
Wheat & 25 & 17 & 12 & 0 \\
Feed grains & 20 & 28 & 20 & 0 \\
Cotton & 20 & 17 & 17 & 0 \\
Oilseed & 30 & 28 & 32 & 0 \\
Sugar & 44 & 42 & 40 & 0 \\
Vegetables and fruits & -10 & -8 & -4 & -2.5 \\
Meat & -20.0 & -19 & -15 & -2.6 \\
Dairy & 30 & 30 & 30 & 0 \\
\hline
\end{tabular}

* The first three volume data stem from Huang and Rozelle (2002). The last volume data comes from assumption as follow: besides vegetables fruit and meat, the nominal protection rate of other goods will drop to 0 by 2010 
Table 3. The Structure of Chinese food and fodder trade during 1980-2003 (million dollars)

\begin{tabular}{|c|c|c|c|c|c|c|c|c|}
\hline & 1980 & 1985 & 1990 & 1995 & 2000 & 2001 & 2002 & 2003 \\
\hline \multicolumn{9}{|l|}{ Export: } \\
\hline Living animal and meat & 745 & 752 & 1221 & 1822 & 1628 & 1976 & 1008 & 973 \\
\hline Dairy & 71 & 57 & 55 & 61 & 188 & 192 & 194 & 222 \\
\hline Fish & 380 & 283 & 1,370 & 2,875 & 3705 & 4231 & 4690 & 5514 \\
\hline Grain, oil and oilseed & 481 & 1,306 & 1,237 & 1,608 & 2667 & 1835 & 2422 & 3714 \\
\hline Vegetables and fruits & 1074 & 1260 & 2293 & 3922 & 4367 & 4931 & 6402 & 7134 \\
\hline Sugar & 221 & 79 & 317 & 321 & 173 & 156 & 227 & 196 \\
\hline $\begin{array}{l}\text { The total export of various } \\
\text { above }\end{array}$ & goods 2,972 & 3,737 & 6,493 & 10,609 & 12,728 & 13,340 & 14943 & 17255 \\
\hline \multicolumn{9}{|l|}{ Import: } \\
\hline Living animal and meat & 6 & 24 & 68 & 115 & 696 & 659 & 706 & 791 \\
\hline Dairy & 5 & 31 & 81 & 60 & 218 & 219 & 274 & 350 \\
\hline Fish & 13 & 44 & 102 & 609 & 1212 & 1319 & 1558 & 1994 \\
\hline Grain, oil and oilseed & 2,472 & 1,065 & 2,535 & 6,760 & 4163 & 5343 & 5825 & 6252 \\
\hline Vegetables and fruits & 104 & 92 & 113 & 259 & 677 & 866 & 838 & 872 \\
\hline Sugar & 316 & 274 & 390 & 935 & 177 & 376 & 238 & 216 \\
\hline $\begin{array}{l}\text { The total import of various } \\
\text { above }\end{array}$ & goods 2,916 & 1,530 & 3,289 & 8,736 & 7,143 & 8,782 & 9439 & 10475 \\
\hline \multicolumn{9}{|l|}{ Net export: } \\
\hline Living animal and meat & 739 & 728 & 1153 & 1707 & 932 & 1317 & 302 & 182 \\
\hline Dairy & 66 & 26 & -26 & 1 & -30 & -27 & -80 & -128 \\
\hline Fish & 367 & 239 & 1,268 & 2,266 & 2493 & 2912 & 3132 & 3520 \\
\hline Grain, oil and oilseed & -1991 & 241 & -1298 & -5152 & -1496 & -3490 & -3403 & -2538 \\
\hline Vegetables and fruits & 970 & 1168 & 2180 & 3663 & 3690 & 4065 & 5564 & 6262 \\
\hline Sugar & -95 & -195 & -73 & -614 & -4 & -220 & -11 & -30 \\
\hline $\begin{array}{l}\text { The total import of various } \\
\text { above }\end{array}$ & goods56 & 2,207 & 3,204 & 1,873 & 5,585 & 4,558 & 5504 & 7266 \\
\hline
\end{tabular}

Source of the data: statistics of China's National Bureau of Statistics (NBS) and the customs for every year.

Table 4. Income per capita of various groups in Chinese different areas in2006 (\%) *

\begin{tabular}{|c|c|c|c|c|c|}
\hline \multirow[b]{2}{*}{ Area } & \multirow[b]{2}{*}{$\begin{array}{l}\text { Group of Accumulate } \\
\text { income }\end{array}$} & \multirow[b]{2}{*}{ of ${ }_{\text {capita }}^{\text {Income }}$} & \multicolumn{3}{|l|}{ Production** } \\
\hline & & & $\begin{array}{l}\text { per Section I: } \\
\text { Section } \\
\text { Competitiveness }\end{array}$ & $\begin{array}{l}\text { Section II: } \\
\text { with Section } \\
\text { Competitiveness }\end{array}$ & without \\
\hline \multirow[t]{3}{*}{ Nation } & Group $1 \quad 0-3.5 \%$ & 491 & 42 & 58 & \\
\hline & Group $6 \quad 40-50 \%$ & 1928 & 53 & 47 & \\
\hline & Group 11 90-100\% & 5889 & 64 & 36 & \\
\hline \multirow[t]{3}{*}{$\begin{array}{l}\text { Western } \\
\text { area }\end{array}$} & Group $1 \quad 0-3.5 \%$ & 356 & 36 & 64 & \\
\hline & Group $6 \quad 40-50 \%$ & 1302 & 56 & 44 & \\
\hline & Group $1190-100 \%$ & 3961 & 52 & 48 & \\
\hline
\end{tabular}


Middle

$\begin{array}{cccccc}\text { area } & \text { Group 1 } & 0-3.5 \% & 459 & 40 & 60 \\ \text { Group 6 } & 40-50 \% & 1785 & 56 & 44 \\ \text { Group 11 } & 90-100 \% & 4726 & 65 & 35\end{array}$

East

area

$\begin{array}{lllll}\text { Group 1 } & 0-3.5 \% & 598 & 47 & 53 \\ \text { Group 6 } & 40-50 \% & 2425 & 50 & 50 \\ \text { Group 11 } & 90-100 \% & 8040 & 74 & 26\end{array}$

* This table selects from Revenue and Expenditure Census in2006 by CSSB.

** Section I is the labor-intensive products (rice, the vegetables, pork, beef, mutton, the poultry, the egg and fish etc.); Section II is the land -intensive products (wheat, maize, feed grains, soybeans, cotton, edible oil, candy and dairy).

Table 5. The result of SURE

\begin{tabular}{|c|c|c|c|c|}
\hline & \multicolumn{4}{|c|}{ SSURE Estimatement } \\
\hline & PI & PGDP & INE & TRADE \\
\hline \multirow[t]{2}{*}{ PGDP } & $-0.868 * * *$ & & $-0.891 * * *$ & $0.594 * * *$ \\
\hline & 7.165 & & 3.794 & 4.478 \\
\hline \multirow[t]{2}{*}{$\mathrm{PGDP}^{2}$} & $0.057 * * *$ & & $0.074 * * *$ & $0.213^{* * *}$ \\
\hline & 6.415 & & 4.165 & 2.360 \\
\hline \multirow[t]{2}{*}{ INE } & $0.132 * *$ & $0.332 * * *$ & & $0.061 * * *$ \\
\hline & 2.124 & 4.456 & & 4.223 \\
\hline \multirow[t]{2}{*}{ AGR } & $-0.246^{*}$ & $0.354 * *$ & $-1.342 * * *$ & $0.241 * * *$ \\
\hline & 2.462 & 3.451 & 7.147 & 4.621 \\
\hline \multirow[t]{2}{*}{ TVE } & $-0.203 * *$ & $0.498 * * *$ & -0.064 & $0.418^{* * *}$ \\
\hline & 3.014 & 4.645 & 0.895 & 3.246 \\
\hline \multirow[t]{2}{*}{ INFLATION } & 0.008 & $-1.016^{* * *}$ & $0.341 * * *$ & $0.089 * * *$ \\
\hline & 0.746 & 8.654 & 6.032 & 5.352 \\
\hline \multirow[t]{2}{*}{ TRADE } & $0.269 * *$ & $0.542 * *$ & $0.142 *$ & \\
\hline & 2.561 & 4.210 & 1.624 & \\
\hline \multirow[t]{2}{*}{ TRADE $^{2}$} & $-0.087 * *$ & $0.132 *$ & $-0.343 * * *$ & \\
\hline & 2.14 & 2.292 & 1.467 & \\
\hline Volume of sample & 465 & 465 & 465 & 465 \\
\hline $\mathrm{R}^{2}$ after adjustment & 0.74 & 0.92 & 0.86 & 0.79 \\
\hline
\end{tabular}

Note: (a) The figure below the estimated coefficient of variables is the absolute value of the test value $t$;

(b) $*, * *, * * *$ respectively state that the estimated coefficients are significantly different from zero at the statistics levels of $10 \%, 5 \%$ and $1 \%$. 